\title{
3 \\ The Road from Laucala Bay
}

\author{
Brij V. Lal
}

\section{Brij V. Lal: Personal Journey}

Two institutions bookend my career. One is the University of the South Pacific (USP) and the other The Australian National University (ANU). One is where I began my academic journey and the other where I completed it four decades later. My gratitude to both is inestimable. One taught me the alphabets of scholarship and the other helped me bring it to fruition. The purpose of education, I learned in my undergraduate years, was the betterment of society. It was deliberately, unequivocally instrumental in nature: scholarship as a means to an end and not an end in itself. Engagement and attachment were essential aspects of our role as educated citizens and leaders of our developing island nations. These values have remained with me after all these years. At ANU, I continued my pursuit of engaged scholarship unfettered by ideology and theoretical dogma and passing intellectual fashion. I learnt the value of living within my own history, not above or outside it. And I did so in the company of men and women of profound scholarship whose affectionate commitment to the Pacific Islands region was inspirational. Their names are legion: Jim Davidson, Harry Maude, Oskar Spate and many more who combined scholarship with practical engagement. At the USP, that role was assumed by Ron Crocombe, the indefatigable promoter of Pacific Island scholarship. They are my inspiration and my role models. It is pleasing that the once-fledging relations between the two institutions that have shaped my life are now flourishing, and the prospects for continued collaboration look brighter by the day. I begin this essay with the place where I began my journey, which led to an improbable scholarly career. 
Lal, B.V. 2013. The Road from Laucala Bay. In L. Crowl, M. Tuainekore Crocombe and R. Dixon (eds), Ron Crocombe: E Toa! Pacific Writings to Celebrate his Life and Work. Suva: USP Press.

Republished with the kind permission of USP Press.

You who will emerge from the flood

In which we have gone under

Remember

When you speak of our failings

The dark time too

Which you have escaped

—Berthold Brecht, 'To Those Born Later'

It is now exactly 47 years since I went to the University of the South Pacific to undertake an undergraduate degree in history and English. I was on a government scholarship to prepare for a career as a high school teacher. The humanities were for the no-hopers, some people in the village said; bright students did law and medicine and other statusenhancing subjects that secured good marriages and prosperous careers. But for me at that time, just getting into university was an achievement of singular importance. I was the first one in my entire extended family throughout Vanua Levu ever to complete high school and the first to head for tertiary education. A career as a high school teacher was nothing to scoff at: it paid well, teachers had a good reputation in the community as exemplars of proper moral behaviour, and the prospect of promotion up the ladder of the educational bureaucracy looked bright. For the generation before us, a lowly career in the colonial bureaucracy was all that could be hoped for at best. Otherwise, it was back-breaking work in the cane fields. The timing was right for us. Fiji had just become independent (in 1970) and there was need for skilled manpower to propel the engine of postcolonial development. We would be the torchbearers of the independence generation.

The opening of the University of the South Pacific was a monumental achievement in the modern history of the Pacific Islands, a genuine turning point, much like the impact of the Second World War, or the beginnings of decolonisation in the 1960s. It placed higher education within the reach of all school children who passed the appropriate exams with requisite marks, not only those who (or whose parents) could afford 
it, or the select few who went overseas on a small number of government scholarships. It was, in its own way, a great leveller of hierarchy based on wealth and status. Unsurprisingly, university education on offer was unequivocally utilitarian, explicitly advertised in the names of the three foundational clusters of academic activity: the School of Social and Economic Development, the School of Natural Resources and the School of Education. All this did not matter to those of us lucky enough to get admission to the university in the first place; getting to the Laucala Campus was quite an achievement in itself. What a time it was. 'I sing of our youth', New Zealand historian Keith Sinclair once wrote, 'And the fierce gladness of being in at the beginning' (1963, cited Stead 2008:8).

Towards the end of my second year, after I had demonstrated a capacity for academic achievement, at least as measured in the final grades, the thought began to enter my head that an academic career might be worth contemplating and not beyond the realms of possibility. Reading in the library for endless hours was enthralling. What could be better than a life devoted to it? In this thought, I was anything but discouraged by some of the faculty, especially by my history lecturer June Cook, the chainsmoking Cambridge graduate who had come to the university after a stint in the United Nations (and who, I was to learn much later, had gone on to bat for me with people like Ron Crocombe, whom she was tutoring in French). The occasional nod of acknowledgement from some of the academics in the corridors, the chance encounter in the dining room, occasionally being called by your first name (after high school, where we remained anonymous, seldom recognised individually) suggested that perhaps one was being noticed, or at least making a small impression.

The university was a liberating experience in many ways: escaping the confining ways of village life in Labasa, encountering new people from other Pacific Islands, the new freedoms and opportunities. Intellectually it widened our horizons in previously unimaginable ways. In high school, we had no local history. For our higher exams, we had studied the great themes of European history: the unification of Germany and Italy, the causes of the First World War, the Russian Revolution, the rise of fascism in Italy and Germany. In earlier grades, we had studied aspects of New Zealand history: the economic policies of Sir Julius Vogel, the rise of the Liberal Party, the life of Sir Apirana Ngata. At university, Tony Chappell's year-long course introduced us to Pacific history, broadly including the cultural anthropology of Pacific Island societies comprising Melanesia, Polynesia and Micronesia. Ron Crocombe, the lean, lanky professor of 
Pacific studies, deepened that knowledge through an extensive reading and anecdote-rich course in Advanced Pacific History. As I have said elsewhere, Ron was not a disciplined teacher, but he was an electrifying one who spoke with deep personal knowledge of the people he had met and the places he had visited. He seemed to know virtually every scholar who mattered in Pacific studies. And as a teacher, he took us seriously, perhaps more seriously than we deserved. I recall vividly Ron giving me a brandnew copy of Pacific Islands Portraits edited by Jim Davidson and Deryck Scarr (1970) and asking me to write a review of it. ${ }^{1}$ Such confidence in one's ability to say something meaningful when one was merely learning the alphabets was daunting at the time, but it was also thrilling. Ron was already publishing third-year research papers as small monographs under the auspices of the South Pacific Social Sciences Association, which he founded. Some essays found an outlet in Pacific Perspective, a new journal he started, typically with the collaboration of senior undergraduates and edited by a junior Islander academic. ${ }^{2}$ It's now gone. I tried to follow Ron's example in my own teaching career. ${ }^{3}$

Suddenly, history did not appear remote or unrelated. I remember distinctly the faces of our Solomon Island colleagues lighting up when the topic of the Pacific Islands labour trade was discussed and names of such places as Kolombangara and Choiseul were mentioned. These were not just names on paper, but names of places intimately familiar to the students. The mention of Efate or Tanna evoked a similar response among the ni-Vanuatu crowd when the history of the sandalwood was discussed. Ahmed Ali's course on colonialism in the Pacific introduced us briefly to aspects of Fijian colonial history, complete with names of familiar people and places, such as Sir Henry Marks, after which Marks Street in Suva was named and familiar to us as the place for affordable Chinese food. John Harre's lectures on the social anthropology of family and kinship

1 Those 'portrayed' were Peter Dillion, the Henrys of Tahiti, King George Tupou I of Tonga, Cakobau and Ma'afu, Xavier Montrouzier, John Coleridge Patteson, Kwaisulia of the Solomon Islands, Lauaki Namulau'ulu Mamoe, Baiteke and Binoka of Abemama, Pacific beach communities, the Pacific labour trade and the planter community in Fiji.

2 Sione Tupouniua was the editor, and editorial committee members included Isoa Gavidi, Lionel Brown, John Samy, Finau Tabakaucoro and Gary Finaly, besides academics Peter Stone and Brian Lockwood.

3 I published a set of senior prize-winning graduate essays at the University of Hawai' $\mathrm{i}$ titled Wansalawara: Soundings in Melanesian History (University of Hawai'i at Mānoa Center for Pacific Islands Studies, Occasional Paper 31, 1987) and Honours essays done under my supervision at the ANU in my Chalo Jahaji: On a Journey Through Indenture in Fiji (The Australian National University Division of Pacific and Asian History and Suva: Fiji Museum, 2000). 
led us to Adrian Mayer's incomparable Peasants in the Pacific (1973), whose description of rural Fiji Indian society was as authentic as it was real. The rituals and ceremonies he described were a part of our life in rural Labasa. Ken Gillion's Fijis Indian Migrants (1962) introduced us to the history of our people, their origins, and early settlement. Ahmed Ali once lent me his thesis to read. More impactful than the subject matter, a history of race and electoral representation in Fiji, was the artefact itself: to see in a perfectly bound volume of several hundred crisp pages neatly typed words about our own history (Ali 1973). All of a sudden, everything became real. The thesis and the books we read whetted my appetite for history and planted the seeds of ambition that I too might try my hand at it one day. But it remained a private ambition, riddled with doubt about its actual realisation. I wasn't very good at transformational grammar, which was a compulsory course in English. Discussion of alpha clause and beta clause left me cold. And I was, after all, on a scholarship to become a high school teacher of English and history.

We were undergraduates at the university at a time of great political optimism in the region. Our islands were in the process of gaining independence, and some amongst us were already marked for great things in the future, such as Barak Sope, who would go on to a mixed political fortune in his native Vanuatu, and the frequently shirtless, tennis-playing Teburoro Tito, who would become the president of Kiribati. Others would become diplomats, senior administrators and educators, a veritable 'USP Mafia' in the region. The atmosphere at university was suffused with the sense that, with the right kind of leadership, ordinary people could make a difference to the nation building that was under way after nearly a century of colonial rule. This was nowhere more evident than at the Social Issues in National Development conference, which Ron Crocombe organised at the university in 1974 (Tupouniua et al. 1975). The occasion was genuinely participatory, featuring international luminaries such as the anthropologist Sir Raymond 'Tikopia' Firth, local academics (Ahmed Ali), political practitioners (Fiji's Karam Ramrakha) and students (Vijay Naidu, Jone Dakuvula and Amelia Rokotuivuna). This emphasis on inclusiveness and Islander participation, on dissolving differences of hierarchy and status, was pure Ron, and it was stirring. The problem of development was considered from a variety of perspectives: anthropological, sociological, economic, historical, political. There was no contrived coherence of themes, no scripted choreography. This too was Ron, assertively multidisciplinary. 'What kind of life do we want for 
ourselves?' Amelia asked (ibid.). One that promoted human dignity and equitable development, she answered. 'We people of the Pacific Islands are in the enviable position of being able to make a choice since most of our nations are just beginning the journey of nationhood' (ibid.). Dakuvula pleaded for 'freedom to examine and criticise,' as the 'unorthodox and the ruled are worth trusting and listening to' (ibid.). Such innocence of those salad days seems so touching in the light of subsequent developments in Fiji and the region generally. After the 2006 military coup in Fiji, Jone, the youthful anarchist, was working for the military regime. Disillusioned, he is now at Fiji's new national university as its Registrar.

The same spirit of innocence was evident in scholarship as well. In 1973, three senior students at the university, Sr Mary Stella, Asesela Ravuvu and Raymond Pillai, all Ron's students, published a joint paper, 'Pacific History and National Integrity', which provided a distillation of thought current at the time. 'An objective study of Pacific history', they wrote, 'will contribute greatly towards overcoming the myth of white superiority which has so discouraged the Pacific peoples from asserting themselves' (Stella et al. 1973:1-7). An important function of history, and scholarship generally, was to instil confidence in people 'eager to make their own contribution' (ibid.). History thus had a constructive role to play 'in promoting the rehabilitation of the Pacific peoples because it restores their confidence and self-respect, and enables them to take their place in a new and changing world' (ibid.). They went on:

If the Pacific peoples are to avoid the pitfalls that have plagued the progress of more complex civilisations, they must glean the pages of history and profit from the experiences of those who have gone before. Leaders in the Pacific need such knowledge in order to make soundly based decisions in their dealings with their own people and with other nations. History will not provide ready made solutions, but the process of analysing the past can be fruitfully applied to the present (ibid.).

Such optimism about the relevance of the past to the present was not confined to USP students and faculty. It was part of the general currency at the time. Delivering the presidential address to the Australia and New Zealand Association for the Advancement of Science in 1970, Harry Maude of ANU too had proclaimed that history:

has a very practical and therapeutic role to enact in assisting the rehabilitation of the Pacific peoples at the end of a traumatic era of European political, economic, and technological ascendancy by renewing 
their self-respect and providing them with a secure historical base to play their part as responsible citizens of independent or self-governing communities in a new world (Maude 1971:24). ${ }^{4}$

Subsequent history would prove that noble sentiment to be sadly misplaced. Once entrenched in power, political leaders disdained discussion and suppressed dissent. As Thomas Jefferson once said, 'Whenever a man has cast a longing eye on offices, a rottenness begins in his conduct'. Pacific leaders were no exception. University graduates were expected to be pliant cogs in the wheels of government bureaucracy, agents of state-sponsored development programs, not independent critics of its policies. Former students who later became political leaders themselves breached the principles of freedom of expression they had so stoutly championed in their youth. And not everywhere in the Pacific was there a single unitary tradition that could be utilised in nation-building efforts. The Papuans were seeking separation from the New Guineans, there was a breakaway movement in the Western Solomon Islands, the ni-Vanuatu were grappling with the divided legacy of colonial rule bequeathed by the British and the French. In Fiji, Fijians and Indo-Fijians had sharply divergent views about the colonial past that seemed only to harden with time.

The age of innocence of the earlier years about the role and importance of history is now gone. History, as a discipline, is taught in schools as part of an amorphous, mind-numbing social science unit rather than as a separate subject in its own right. It is a devalued currency in modern education in the islands. In universities, the sanctity of disciplinary boundaries is rejected as archaic. We now speak of 'histories' in the plural, contested, problematised, intersected along a myriad lines by a variety of concerns, interests, understandings and authorial subjectivities. We now live with the certainty that scholarship is partial in both senses of the term. ${ }^{5}$ I accept these new developments intellectually, though I am also troubled by them. Doubt in small doses is salutary, but it can be disabling when taken to excess. Pluralism, diversity and fragmentation can be liberating, but so too can an exercise in synthesis, an overarching connected narrative to understand the larger shape of the human experience. I also tire quickly of the endless language games scholars play, usually for the edification

4 Maude retired to an academic career after a lifetime as a colonial civil servant. His academic colleague J.W. Davidson was active in advising Island people during their transition to independence.

5 For more on this, see Thomas (1990). 
and amusement of each other. The habits of thought I acquired in my undergraduate years about the place of the humanities in the broad cultural life of a civilised society have persisted. I am comfortable with that.

There were several other things about my USP background that I observed quietly at the time but whose full importance I did not grasp. Among them was the literary renaissance that was taking place at the university in the 1970s and 1980s. Students and creative writers were beginning to write imaginatively about their own societies. Their works appeared first in the student journal Unispac and later in Mana, the publication of the South Pacific Creative Arts Society started by Marjorie and Ron Crocombe and Albert Wendt, among others. I was particularly fascinated by stories about the Indo-Fijian community, about which so little had been written, almost as if the world we came from was not worthy of literary exploration and critical engagement. We read pieces by Raymond Pillai, Anirudh Singh, Dhurup Chand, Sashi Kant Nair, Sulochana Chand, and others. Raymond was everyone's favourite. ${ }^{6}$ He wrote with unerring clarity and authenticity about the world of rural Indo-Fijians. We understood perfectly what he meant about the stillness of village life being a 'cloak, like the veil a woman wears before strangers, hiding private life full of tragedy and violence' (Pillai 1980:15). When he wrote about Bangaru being black as a baigan (eggplant), we knew exactly what he meant. There was a Bangaru in every village. Vanessa Griffin introduced us to the world of Fijians and part-Europeans. Her word pictures were so true: 'This Fijian woman, any Fijian woman, was a common sight on the sea wall, sitting couched, with faded cotton skirt billowing in the wind, or standing against the sky,' with a 'basket plaited out of green coconut leaf' containing her bait (Griffin 1973:91).

The voices that Raymond, Vanessa and others captured were not found in archival documents so beloved by historians. It seemed to me then, and the conviction has deepened with time, that these writers were better able to capture the lived experience, its mystery, its rich daily texture, far better than conventional scholars. These creative pieces and the idea that our people had such wonderful stories to tell lodged deep at the back of my mind, and I have the lingering suspicion that they had something to do with my own efforts at creative writing later in my career. Sadly,

6 His two published collections of short stories include The Celebration (Suva: Mana Publications and South Pacific Creative Arts Society, 1980) and, posthumously, The End of the Line (Suva: Fiji Institute of Applied Studies, 2008). 
though, the promise of a literary renaissance at the Laucala campus was short lived, ruptured by the coups of 1987 when the leading artists left for other shores or stopped writing altogether. It was revived in the mid-1990s by the Niu Waves group only to be disrupted by George Speight's insurrection in 2000. After the latest coup in 2006, a culture of silence and self-censorship has descended on Fiji's creative community, sadly with the silent support of its pliant academic hierarchy.

The idea of literature providing a window into the truth of the lived human experience was expressed most powerfully by Albert Wendt. Two things he said stayed with me. The first was the notion that there is no one perfect way to write history, that it could be written from a variety of perspectives. 'A novel is a history,' he wrote, 'an analogue of the real world, written by someone for whom life is a perpetual question and for whom there are no sacred truths'. The world the novelist sought to create 'attempts to explore all his possibilities, tries to be total, to include even the dreams/fantasies/smells/prophesies/and diseases of a particular place which exists outside time'. The difference between the two was that 'a historian tries to recreate a world that, according to historical evidence, was, and save it for all time'. But it was still fiction 'because it is selective recreation, and Art being selection ain't life'. Both were custodians and creators of memories as mythographers and mythmakers who 'explore our possibilities: the novelist through supposedly "imaginary" people and situations, the historian through people who supposedly existed. And in a world where the gods are dead, they both create their own meanings in the hope that those meanings will sustain them' (Wendt 1987:78-92).

At the time, Wendt's contentions seemed heretical, unsettling to those of us just beginning to learn the alphabets of academic disciplines. We were taught to believe that the past had a reality of its own that could be revealed through the use of proper methods of enquiry. We had our own codes and distinctive protocols of research, just as other disciplines had theirs. We were not in the business of 'creating our own meanings', but telling objective truths ascertained through verifiable evidence, this being one of the central tenets of historical scholarship. ${ }^{7}$ The idea that historians were mythmakers seemed strange to us, disturbing; on the contrary, we fancied ourselves as myth busters, setting the record straight. But over time, I have come to accept the essential truth of Wendt's contention, though not

7 See, for instance, Novick (1988). 
perhaps all of it. And I have also become more mindful of historian Ken Inglis's observation that 'a lot of history is concealed autobiography' (Inglis 1983:1). We live within, not outside, the histories we write. We end up creating texts that are partial. We reject the notion of value-free research in its entirety and of linear, one dimensional truth. We accept the role of imagination in the construction of human knowledge. And we readily acknowledge the distinct possibility of becoming a footnote in someone else's text in our own lifetime rather than penning transcending, timeless texts.

The other disturbing question Albert Wendt asked touched on issues of the representation of the past. It was not so much a question of who should or should not be allowed to write history. 'The crucial question,' Wendt argued, was, 'Can a historian ever get into the brain and blood of someone whose culture is so different from his own, and write from inside that person? And should he pretend he can?' These are important questions and I am not sure I have a clear or adequate response to them. Meanwhile, I do have questions to raise. Is it ever possible for anyone to get into the blood and bones of people long dead and gone? Isn't the past a foreign country to all of us? Is it ever possible to know the 'really real'? Insider cultural knowledge certainly confers some advantages, but cultural traits are learned not innate, and there are ample examples in Pacific studies of scholars writing sensitively about indigenous cultural matters and accepted as such by the people themselves. Think of Roger Keesing, David Hanlon and Marshall Sahlins, to take just three examples.

Over time, I have come to question some of the assumptions and parameters of positivist scholarship characteristic of an earlier generation. I do not deny the enormous value of archival research, but I have also become aware of its many limitations. Documents about the past are not neutral pieces of paper. They were written by people in particular contexts for particular purposes. They are instruments of and for power and authority. They have an agenda of their own. Those who questioned the foundations of the duly constituted architecture of power were dismissed as madmen, misfits and mavericks. Students of Fijian history would know the fate of the Fijian rebel Apolosi Nawai. In the 1960s, the IndoFijian leader A.D. Patel was subjected to sustained attacks for demanding independence. So it is important to read the historical records not only for what they say, but, perhaps equally importantly, what they leave out. Sometimes, the silence can be deafening. 
Archival research privileges a particular kind of historical narrative. The written word provides the foundation of the project, enlivened wherever possible with oral and anecdotal evidence, although, until recent decades, non-written sources that could not be properly authenticated or verified were not accorded much weight. But what about histories of pasts where memory is not properly archived and written evidence does not exist? What, in other words, about the histories of unwritten pasts and peoples? Let me give a concrete example of what I have in mind. I grew up in a rural settlement in Fiji in the 1950s and 1960s. People had begun to settle on haphazardly leased pieces of land in the settlement soon after the end of indenture in 1920. Of little interest to the government except for purposes of rudimentary administration, the Indo-Fijians had to rely on their own cultural resources to establish families and farmsteads, create institutions that regulated social life in the villages, adjudicated disputes, celebrated life and mourned its passing. It was in these settlements that the main features of Indo-Fijian culture were fashioned from bits and pieces of the remembered past and the accumulated experience of the new environment. I came from this world that formed me and the people of my generation, but there was hardly anything written about it. It was almost as if that world did not exist, or did not matter. How to write truthfully about this past began to preoccupy me more and more. Albert Wendt's advice about capturing the spirit of the place, not only its dry facts, kept returning to me.

To make some sense of my lived reality, I began to write what I have termed 'faction', where I try to capture the actual lived experience in fictional or quasi-fictional terms. ${ }^{8}$ I write about things I have observed or experienced, about stories I have been told: a family quarrel, the politics of running local schools, religious and cultural tensions-and I write about them creatively but with disciplined imagination. Unlike a novelist, I cannot conjure something out of thin air. I work with material given to me by experience or observation, and from that I create a connected narrative. Perhaps this is what novelists do as well, I do not know. My concern is to capture the inner truth rather than the factual accuracy of an experience. The experiment has worked for me over the years. I have received dozens of appreciative messages from readers across the world who have found my factional pieces authentic, reflecting their own

8 See my Mr Tulsi's Store: A Fijian Journey (Canberra: Pandanus Books, 2001) and Turnings: Fiji Factions (Lautoka: Fiji Institute of Applied Studies, 2008). 
experiences. ${ }^{9}$ Understandably, there will be many who will question the scholarly 'value' of this kind work. The truth of what I write in factions cannot be verified as a piece of archival evidence might be, but that is the best way I know how to get to the truth of an unwritten experience, to the blood and bones of the people I write about. And the truth, as they say, lies in the taste of the pudding.

Albert Wendt's point about the possibility of writing the history of another culture also raises pertinent questions with which I have grappled in my own work. I recall Ron Crocombe once telling me that he vowed not to conduct research on Fiji when he took up his appointment at the university. He wanted complete freedom to research and write about things that mattered to him without having to worry about the renewal of his work permit. If he could not write the truth as he saw it, he wouldn't even try. He kept his word. For a very different reason, I made a conscious decision from very early on to write about my own people and my own country. I do not want to be an intruder on someone else's past. There have been occasions when I have written about other places, but the primary site of my scholarly investigation has been Fiji. I am moved by a strong sense of belonging and attachment. It is where my head and my heart come together. I am a part of the history I write about. I may get things wrong, but at least it is my place and my history. I will bear the burden of my errors. I have a deep sense of responsibility and obligation to it. I care about the region of which I am a part, but not with the same passionate intensity that I feel about Fiji. My choice is political, not intellectual. I see no reason why an outsider cannot feel passionately involved about the place of his or her research endeavour. Nor do I feel particularly possessive about my site of research. The more research we have the better. It is the quality of engagement, not the colour of skin, that will matter in the end.

For a while, the 'ownership' of scholarship was a deeply contested and politically contentious issue in Pacific studies. ${ }^{10}$ Did outsiders have the right to 'appropriate' someone else's history? Some saw scholarship as a deeply political act, and the involvement of outsiders as complicit in the process of academic imperialism. I encountered this most directly at the University of Hawai' $\mathrm{i}$ while teaching there in the 1980s, where

9 Mr Tulsi's Store was selected as one of the Ten Notable Books of Asia Pacific by the San Franciscobased Kiriyama Prize in 2002, and chosen as Highly Commended for ACT Book of the Year in 2002. 10 See, for example, in addition to Nicholas Thomas (footnote 5), Routledge (1985) and Hezel (1988). 
issues of dispossession, marginalisation and indigenous sovereignty were acute and dominated public discourse. Unless history was taught from a particular ideological standpoint, deployed in the cause of indigenous empowerment, however defined, it was unacceptable and therefore to be rejected outright. Emotions were aroused and brought into sharp focus in an exchange between the anthropologist Roger Keesing and the Hawaiian scholar and activist Haunani-Kay Trask. Trask accused Keesing of being an academic 'colonialist', part of a 'colonising horde' who sought to 'take away from us [natives] the power to define who and what we are, and how we should behave politically and culturally' (Trask 1990:159-67). Arguing that 'anthropologists without natives are like entomologists without insects', she accused Keesing and other expatriate anthropologists of profiting from native cultures by studying and writing about them in academic institutions (ibid.). Keesing accused Trask and others like her of romanticising the past of Pacific cultures and drawing too rigid a line between outsiders and insiders.

The time is long past where those who are friends of Pacific Islanders and Islands and those who are enemies can be sorted out on the basis of their genes or skin colours: there are plenty of 'insiders' many with Swiss bank accounts, busily selling their forests, their minerals, their fish-the lives and environments of the village cousins and their own children and grandchildren — to foreign interests (Keesing 1990:168-71).

Similar issues about representation and legitimacy were raised elsewhere in the Pacific, again producing rather more light than heat.

But these debates, which were once so animated and controversial, have lost their relevance and potency now. The boundaries of knowledge and power are more porous now, as are dated essentialised notions of cultural identity. The traditional gatekeepers of knowledge have had their function usurped by modern technology. Many practitioners of Pacific studies today are Pacific Islanders themselves, some in positions of power and influence. ${ }^{11}$ Given the paucity of serious scholars engaged in serious study of the islands, people are grateful for knowledge and insight irrespective of their origin. In the scholarship produced in recent years, there has been a great degree of emphasis on local context and agency, on indigenous epistemology, with the result that some of the older criticism of

11 Vilsoni Hereniko is Director of the Center for Pacific Islands Studies at the University of Hawai'i; Teresia Teaiwa is Convenor of Pacific Studies at Victoria University of Wellington and Katerina Teaiwa is Convenor of Pacific Studies at The Australian National University. 
imperialism and insensitivity has lost its effectiveness. It is also important that the geographical boundaries of the Pacific Islands have greatly expanded, thereby necessitating a re-thinking about what constitutes the 'real' Pacific. ${ }^{12}$ There are many more Pacific Islanders-Samoans, Tongans, Cook Islanders, Niueans, Tokelauans-who now make their homes in Australia and New Zealand, thus complicating the outsider/ insider paradigm. On the present evidence, these diasporic communities will gain in strength and influence in the future. The centre of gravity of island writing and scholarship is shifting to metropolitan locations. Further, some of the romance associated with the study of the Pacific Islands that suffused the earlier generation of Pacific scholarship has now vanished in the face of the trouble and turbulence that is an enduring part of the contemporary Pacific. Pope John Paul's 1985 declaration of Fiji as 'the way the world should be' would now be seen by most people as a cruel joke.

The journey I began at the University of the South Pacific all those years ago was influenced by people who taught us by their example and inspiration. It should be clear by now how much this has been a factor in my own intellectual development. We were trained to be generalists, and there was no provision for academic specialisation in the university curriculum. Karl Popper, Karl Marx and Max Weber made brief appearances in some courses, but there was no sustained engagement with their ideas. There were thus big gaps that had to be filled through private study. Scholarship in the western academy, or at least where I have worked, is organised along disciplinary lines with the result that a lot of time had to be spent simply learning the discipline's history, philosophy and development, the sort of thing that better undergraduate students in history in western universities would have encountered much earlier in their education (such as Lord Acton, R.G. Collingwood, E.H. Carr, G.R. Elton and E.P. Thompson). And the field's literature too had to be mastered. Pacific history could not be learned or taught in isolation from the histories of other regions or cognate areas about which we knew very little. We had no anthropology at the university and yet it was a discipline with special relevance for the study of the Pacific. The practice of reading for the sake of general knowledge and for sheer pleasure had to be cultivated, which was never

12 See, for instance, essays by Epeli Hau'ofa and others in Waddell, Naidu and Hau'ofa (1993). 
easy for people coming from non-literate, oral cultures. Now reading is an integral part of my being, indispensible to sanity. For me, most knowledge still comes from the written text, not the latest technology.

People of my generation had no sense of entitlement that some now seem to have. Education in Australia is big business, and universities regularly compete for foreign students. Special help is assigned to them to improve their literacy and research skills. Everyone naturally wants to preserve the goose that lays the golden egg. But there was none of this for people of my vintage. We were expected to pick up the skills on our own as we went along by reading journals and books. And when it came to writing the dissertations, we were again very much on our own. I recall my designated advisor, Ken Gillion (my formal supervisor was Anthony Low who was then the vice chancellor), telling me that if after six months of reading in the library I was not on top of my subject, the most knowledgeable person in the world, I should not be doing graduate work. That kind of confidence could be debilitating, but it was fairly standard fare then. Students who had arrived on scholarship to pursue graduate work had gone through a rigorous process of selection, and the best thing that could be done for them, it was thought, was to leave them alone to get on with their work. And it worked.

After three years of labour, we were expected to submit three hardbound copies of our dissertation for examination by three scholars who were leaders in the field and had had no contact with the candidate. We were expected to make a distinctive and significant contribution to knowledge by the 'highest standards of contemporary scholarship'. The dissertation had to be as perfect as we could make it. Too many spelling errors and we could expect the examiners to reject it outright. Nothing could be worse for a young postgraduate student contemplating an academic career than to have his or dissertation rejected. There was a certain stigma attached to a dissertation that required re-submission. Word was quick to get out, and chances of securing a decent job at a decent university could be at risk. I was horrified some years ago when a candidate whose dissertation I had examined, pointing out numerous spelling and stylistic errors, told me the advice his supervisor gave him. The examiners, he had said, would point out the errors, which the student could then incorporate in his revision before the final submission. Such advice would have been unthinkable in our day. Now, it seems, many (but by no means all) students expect to make corrections after examination as a matter of course. 
Graduate research is now fairly commonplace, at least in Australia, and doctorate is not in as short a supply as it once used to be. But 30 years ago, the criterion for admission to graduate work was fairly strict. Scholarships, by convention, were given to students not much over 30; anything beyond that age required special pleading. At least in the humanities and the social sciences, it was expected that students would go on to an academic career, not an unreasonable expectation at a time when universities were expanding rapidly. At any rate, graduate training was a prelude to a career. That is not universally the case now. There are now more mature age students in universities who pursue graduate work more out of interest rather than with any expectation of an academic career in prospect. Indeed, an academic career may not be the most lucrative either. In Australia at least, opportunities in the public sector can be financially and professionally more rewarding. Even those who pursue an academic career are now routinely resigned to the possibility of moving on to several jobs in a lifetime.

The research culture has also changed. 'Curiosity driven research' was the order of the day when I entered the academy, and for me it has remained that way. We were expected to work on topics that interested us and to make significant original contributions. Historical research was essentially an individualised enterprise. That was the strength of the work. The accounts we wrote were influenced by the moral and ideological position of the author, not something devised by a committee. Articles were useful in alerting the world to our work, but, ideally, historians were expected to write books at respectable intervals that would make a decisive intervention in the field and would have a longer shelf life. We might be expected to make the occasional foray into the public domain on some important event or controversy, but too much media exposure was not deemed desirable. It detracted from detachment and objectivity. Now, media monitoring is a regular part of a university's public relations exercise. We are expected, indeed obliged, to go beyond the lecture hall to make our expertise available to the wider public. In appropriate doses, this is a healthy and welcome development as part of general public education and engagement, but the demands increase daily for briefing and commentary. Salesmanship and showmanship are increasingly becoming an integral part of a scholar's life. I suppose it could be argued that reaching the general public is an important obligation of taxpayer-funded universities. There are other new developments to which we have to respond. Now scholars are routinely expected to apply 
for research grants. Indeed, in some cases, the ability to attract grants becomes a criterion in appointments and promotions. Grants not only support individual research, they also sustain the infrastructure of an academic department.

On paper, the pursuit of grants seems fair, but upon closer inspection much more problematic. To start with, grants are advertised with particular agendas in mind and focus on strategic areas with some relevance to the broader concerns of the Australian community: border protection, national security, asylum seekers, and so on. Areas that fall outside the prescribed parameters find it harder to get up. 'Cutting-edge research' is often an important factor in assessment. Although it is not stated, the truth is that research that does not somehow fit in with the reigning theoretical paradigm or conceptual category would not ordinarily count as cutting-edge research. Sometimes what is cutting-edge research today is yesterday's news tomorrow. It would seem to me that this requirement is more appropriate to policy-oriented, outcome-driven research. We were brought up in the tradition of humanities requiring a deep immersion in the culture, language and traditions of the people about whom we wrote, our research informed by a lifetime's work. That tradition is now in jeopardy, which is a pity because the finest research on the Pacific Islands came from those scholars who pursued individual research projects. ${ }^{13} \mathrm{I}$ am not convinced, on present evidence, that large grant-supported research necessarily produces more insightful or enduring scholarship, especially when the outcomes have to be produced in a hurry. I see some serious problems in historians and other practitioners of the humanities being forced to march at the pace and tune set by economists and other social scientists whose intellectual agendas and approaches are significantly different. Reviewing a recent biography of historian Sir Keith Hancock, Geoffrey Bolton, himself an Australian historian of note, remarked how long it took the author to publish the book. 'How fortunate', he wrote, '[that Jim] Davidson's university did not insist that he should instead churn out numerous articles in refereed journals as index of research productivity' (Bolton 2010). How fortunate indeed. The question remains: Is the day of the big book, the fruit of a lifetime's learning and scholarship, over? Are we publishing more and more about less and less?

13 The names are legion: J.W. Davidson, H.E. Maude, Dorothy Shineberg, O.H.K. Spate, Deryck Scarr, Hank Nelson. These are all people associated with ANU. 
The pressures to conform are not likely to cease anytime soon. In a globalising world, higher education is increasingly interconnected. International ranking systems matter. Universities high in ranking and prestige attract more funding and better faculty as well as graduate students. Universities run on paper, and the more peer-reviewed paper is produced the better. In Australia, academic journals are ranked and the research published there rewarded. The precise criterion of ranking is not clear, but their influence is beyond doubt. Emphasis on excellence in writing and research is vital and should receive priority in every academic institution worth its name. There is, moreover, a certain professional satisfaction in being published in peer-reviewed places. But sometimes this becomes an end in itself, which leads to the question: What and for whom is the research being done? For fellow researchers, to be sure, but for those of us working on non-western regions such as the Pacific Islands, the question is more complicated, touching on the issue of ethical responsibility we have towards people about whom we write. Books published by prestige publishers are invariably beyond the reach of most of the reading public and most high-ranking journals unaffordable.

So we end up being caught between two sets of loyalties: loyalty to the institutions where we work and their demands and expectations, and the needs and expectations of the people and places where we conduct our research. Sometimes the issue is complicated by the absence of any scholarly outlet in the islands themselves where our research could be published. There were once many, now there are few. There is, for instance, not a single scholarly journal in the humanities coming out of USP, a curious regression considering that there were several two decades ago. Fortunately, the timely intervention of technology has helped; that is, the phenomenon of the internet and e-publishing. Works published by ANU Press, for instance, are available free of charge to everyone. Readers can download particular items in a book or the entire book itself. Electronic publishing may be the way of the future. It has not acquired the prestige of conventional publishing, but it is a matter of time. I understand and accept the reality of the changed circumstances of scholarly publishing, but it still takes some getting used to for people of my vintage for whom printed books are cherished cultural artefacts that occupy a privileged niche in the intellectual life of society and, as someone once said, like telescopes, compasses and sextants 'help us navigate the dangerous seas of human life'. 
I have sometimes been accused by friends and foes alike of being an unrepentant elitist, once an insider but now looking austerely and judgmentally at the local scene from the comfort of a privileged chair from the outside. There may be a grain of truth in this perception, but it does genuinely dismay me to see opportunities not grasped and potential not realised among people who have much to contribute. It is particularly disheartening to see students being short-changed by their mentors when what they most need is role models of scholarly excellence. Exalted polemic is no substitute for solid scholarship. I accept that a university is a not a social security institution. It is, as it has to be, an inherently elitist institution that rewards merit and meritocracy above all else. My creed is best expressed in the inspiring words of the late great historian and public intellectual Tony Judt:

Universities are elitist: they are about selecting the most able cohort of a generation and educating them to their ability — breaking open the elite and making it consistently anew. Equality of opportunity and equality of outcome are not the same thing. A society divided by wealth and inheritance cannot redress this injustice by camouflaging it in educational institutions-by denying distinctions of ability or by restricting selective opportunity-while favoring a steadily widening income gap in the name of free market. This is mere cant and hypocrisy (Judt 2010:6).

I believe that scholars have a vital role to play in society, none being more important than a willingness to speak truth to power. We should guard against the temptations of power, maintain a certain distance and detachment from it that keeps us alert to the ways in which public memory is hijacked in the service of those who govern our lives. Am I being unduly optimistic, hopelessly idealistic? 'Still bent to make some port he knows not where/ Still standing for some false impossible shore' (Arnold 1855)? But what, in this levelling world, is the alternative when, as New Zealand literary polymath C.K. Stead writes, 'universities which once set stiff requirements for entry now advertise for students and compete for market share' (Stead 2008:8)?

Over time, I have become much more attuned to the political interests and concerns that underpin a lot of academic activity. Nothing is ever so simple or neutral as it seems. The day of the 'God Professors' who once ran academic departments with unfettered power, influencing individual destinies and broad directions of research, is over. So, too, is the once common practice of 'tapping someone on the shoulder' for a job. The academic practice is much more open and transparent, at least on paper. 
But ideas of what is valid and proper vary from place to place. At USP, the question most often asked at appointment times was: how many Pacific Islanders are there on the staff, as opposed to expatriates or 'Indians'. Few raised questions about gender equity. Ethnicity of regional origin was the primary marker of identity. In Australia, certainly at my own university, gender equity is a very serious consideration in any appointment process. Women are often alerted to new employment opportunities and encouraged to apply. I am not sure if we seriously ask how many Pacific Islanders or Asians there are in centres of Asian and Pacific learning in Australia. These are important issues, and they speak to different political and cultural concerns and contexts. I just hope that in our quite legitimate concerns for social equity, we do not lose sight of what, in the end, the true purpose of a university is.

There is no shortcut to success. The journey was much harder for my generation, moving from the world of pre-literacy to literacy within the span of a single lifetime. Being an academic is not only an occupation, it is a sacred responsibility, a distinctive way of life with its own overarching cultural codes, protocols and rituals. To succeed, it requires discipline, a cultivation of solitude, cultural re-invention and a deep humility. As Longfellow said a long time ago, 'The talent for success is nothing more than doing what you can do well, and doing well whatever you do without a thought for fame' (Longfellow 1887). Our tasks ahead are clearly defined. We must continue to produce and publish research that adds a vital sentence to the larger global conversation of scholarship. There is no substitute for excellence. We owe that to those who laid the foundations for us in those distant and difficult days, and to those who will inherit the torch from us in uncertain and demanding times. We must engage critically and sensitively with the outside world, breaking the mould of self-referential, 'ghettoising', inward-looking academia. Our natural home should be the interface between the world of scholarship and the world of the lay public. And finally, in this era of galloping globalisation, we should do everything in our power to revive the centrality of the humanities in the cultural life of humankind and in deepening our understanding of the human condition, past and present. As Stephen Garton and Elizabeth Webby argue, 'If our innovation culture is to prosper, it needs to be embedded in a deep understanding of humanity and cultural difference. This is why humanities are fundamental to human progress' (Webby and Garton 2010:4). 


\section{References}

Ali, A. 1973. Fiji and the Franchise, 1900-1937. PhD thesis, unpublished, The Australian National University.

Arnold, M. 1855. A Summer Night. Poems: Second Series. London: Longman, Brown, Green, and Longmans.

Bolton, G. 2010. History's wily liberal endures. The Australian, 3 April.

Davidson, J.W. and D. Scarr (eds) 1970. Pacific Islands Portraits. Wellington: A.H. \& A.W. Reed.

Gillion, K. 1962. Fiji's Indian Migrants: A history to the end of indenture in 1920. Melbourne: Oxford University Press.

Griffin, V. 1973. Marama. The Mana Annual of Creative Writing. Suva: South Pacific Creative Arts Society, 91.

Hezel, F.X. 1988. New Directions in Pacific History: A Practitioner's Critical View. Pacific Studies 11(3):107.

Inglis, K.S. 1983. This is the ABC: The Australian Broadcasting Commission, 19321983. Melbourne: Melbourne University Press, 1.

Judt, T. 2010. Meritocrats. The New York Review of Books, 6.

Keesing, R.M. 1990. Reply to Trask. The Contemporary Pacific 3(4):168-71.

Longfellow, H.W. 1887. Hyperion. London: George Routledge.

Mayer, A.C. 1973. Peasants in the Pacific: A Study of Fiji Indian Rural Society (2nd ed.). Berkeley: University of California Press.

Maude, H. 1971. Pacific History_-Past, Present, Future. Journal of Pacific History 6(1):24. doi.org/10.1080/00223347108572180

Novick, P. 1988. That Noble Dream: The 'Objectivity Question' and the American Historical Profession. New York: Cambridge University Press.

Pillai, R. 1980. Muni Deo's Devil. Celebration: A Collection of Short Stories. Suva: South Pacific Creative Arts Society, 15.

Routledge, D. 1985. Pacific History as Seen from the Pacific Islands. Pacific Studies 8(2):81-100.

Stead, C.K. 2008. Book Self. Auckland: Auckland University Press, 8. 
Stella, M., R. Pillai and A. Ravuvu 1973. Pacific History and National Integrity. Pacific Perspectives 1(2):1-7.

Thomas, N. 1990. Partial Texts: Representation, Colonialism and Agency in Pacific History. Journal of Pacific History 25(2):139-58.

Trask, H. 1990. Natives and Anthropologists: The Colonial Struggle. The Contemporary Pacific 3(4):159-67.

Tupouniua, S., R. Crocombe and C. Slatter (eds) 1975. The Pacific Way: Social Issues in National Development. Suva: Institute of Pacific Studies.

Waddell, E., V. Naidu and E. Hau'ofa (eds) 1993. A New Oceania: Rediscovering Our Sea of Islands. Suva: University of the South Pacific School of Social and Economic Development.

Webby, E. and S. Garton 2010. Editors' Introduction. Humanities Australia 1(4):4-5.

Wendt, A. 1987. Novelists and Historians and the Art of Remembering. In A. Hooper, S. Britton, R. Crocombe, J. Huntsman and C. Macpherson (eds), Class and Culture in the South Pacific. Suva: Institute of Pacific Studies, University of the South Pacific, 78-92. 
This text is taken from Understanding Oceania: Celebrating the University of the South Pacific and its collaboration with The Australian National University, edited by Stewart Firth and Vijay Naidu, published 2019 by ANU Press, The Australian National University, Canberra, Australia.

doi.org/10.22459/UO.2019.03 